\title{
TAIDE TUNTEIDEN OPETTAJANA AMMATILLISESSA KOULUTUKSESSA
}

\author{
Artikkelin tavoitteena on lisätä keskustelua ammattikorkeakoulun tieto- \\ käsityksestä ja opetuksen muodon ja sisällön välisistä yhteyksistä aika- \\ kautena, jossa käytännön pedagogiikkaa koskeva retoriikka näyttäisi \\ määräytyvän talouspolitiikan ja tietotekniikan kehityksen kautta.
}

A mmattikorkeakouluopetuksen tietokäsityksen on havaittu nousevan kahdesta valtaväylästä: työelämälähtöisestä ja tiedelähtöisestä. (mm. Kauppi 2003, 7.) Terveydenhuollon koulutuksessa hoitotieteellinen tieto on vahvistunut ja vähentänyt muiden tieteenalojen ja tieteen ulkopuolisen tiedon merkitystä (Karttunen 2003, 34). Teoria- ja tiedeorientoituneessa ammattikorkeakoulutuksessa on itseohjautuvuus, säästötoimien ohjaamana, ymmärretty yksin opiskeluna. Kun tiedeperusteisuus ja itseohjautuvuus ovat muodostuneet keskeisiksi opiskelua ohjaaviksi arvoiksi, ovat ryhmässä työskentely ja sen kautta saavutettavat yhteistyö- ja tunnetaidot jääneet vähemmälle huomiolle. Keskustelu tunteiden merkityksestä oppimisessa ja työelämässä on voimistumassa tunneälyn ${ }^{1}$, tunnetaitojen ${ }^{2}$ ja tunnetyön ${ }^{3}$ tutkimuksen kautta. (mm. Hochschild, 1983; Goleman 1999; Isokorpi, 2003; Molander, 2003.) Kognitiivis-rationaalisen ajan piirteenä voidaan nähdä tunteiden mukaanotto ja "salonkikelpoisuus" kun tunteita tarkastellaan älyn muotona. Tunteet ja tunnetaidot ovat toiminnan keskiössä etenkin ammattialoilla, joissa eletään sellaisten ihmisen olemassaoloon liittyvien kysymysten parissa, kuten terveys, sairaus, haavoittuvuus tai kuolema. Tällainen ammattiala on esimerkiksi terveydenhuolto, jonka keskeisiä ammattikvalifikaatioita ovat yksilölliset ja ryhmän tunnetaidot. Tässä artikkelissa tunteiden ymmärretään liittyvän ihmisen persoonallisuuden monikerroksisuuteen, koostuen useista erilaisista osatekijöistä. Koettuina ne ovat laadullisia tuntemuksia, spontaaneista tilannearvioista nouse- via, niillä on intentionaalinen kohde, ne ovat pohjimmiltaan arvo-orientoituneita, niillä on maailmankatsomuksellis-intuitiivinen sävy, niihin liittyy fysiologisia muutoksia ja niillä on myös luonteenomaisia fyysisiä ilmenemismuotoja. ( Puolimatka, 2004, 30-32.) Tunteet ovat vahvasti myös sosiaalisia ja kulttuuri- ja yhteisösidonnaisia.

Olennaista terveysalan ammattitaidon tunnetyössä on kyky eläytyä toisen tunne- ja

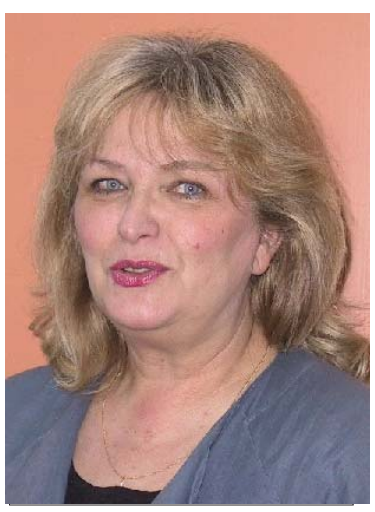

Annukka Häkämies kokemusmaailmaan tiedostaen, mikä koetussa on itsestä nousevaa projektiota ja mikä toisen omaa kokemusta. Tunnetaitojenkin alueella vaaditaan eriasteista osaamista. Esimerkiksi mielenterveystyön ja psykiatrisen hoitotyön ammatillisessa koulutuksessa eivät yleiset vuorovaikutusopit riitä terapeuttisen minän kehittämiseen. Kyse on persoonallisesta olemisen terapeuttisesta taidosta (art of being), yhdistettynä osaavaan toimintaan (knowledgeable doing) (Watkins 2001, 191). Työskentely tunnevaltaisilla aloilla tuottaa myös tunneuupumusta. Väitän, että tunnealueen kokemukselliseen ymmärtämiseen ei vahvasti tiedeperusteisessa, yksilötyöskentelyä korostavassa oppimiskulttuurissa ole riittävästi tilaa tai keinoja. Taiteet ja esteettiset kokemukset tunnekielenä ovat eräs väylä tunnealueiden ja ammatillista toimintaa ohjaavien arvojen tiedostamiseen. 


\section{DRAAMA - ELÄMÄNTILANTEITA TUTKIVAA OPISKELUA}

Mistä draamallisessa oppimisessa on kyse? Mitä sillä voidaan saavuttaa?

Kun opiskelun kohteina ovat tunteet, vallitsevat mielialat ja monimutkaiset ihmistenväliset suhteet, on draama ehkäpä kaikkein taloudellisin oppimis- ja viestintätapa.(Esslin, 1980, 19) Draamatyöskentely perustuu teatteritaiteen työmuotoihin. Sen lähtökohta on toiminnassa (kreik. dran) ja fiktiiviseen tarinaan astumisen riitinomaisuudessa (kreik. dromèna). Teatterin muodon on katsottu soveltuvan hyvin juuri ihmissuhdetaitojen kehittämiseen ja mielenterveyttä edistävään kasvatus- ja terapiatoimintaan. (Cattanach 1995; Esslin 1980, 19; Levanen 1998, 215.)

Käytän tässä artikkelissa, samoin kuin tutkimuksessani, yleiskäsiteitä draama ja draamatyöskentely, jotka pitävät sisällään laajan variaation erilaisia, tavoitteisiin soveltuvia draaman työtapoja. Draama toimii sekä sisällöllisenä opettajana että muotona oppia. (Östern 2003, 33.) Kaikille näille työmuodoille on yhteistä ryhmässä tapahtuva, osallistava työskentely. Toiminta on tutkivaa ja tarinoihin kietoutuvaa. Oppimispotentiaalin oletetaan draamassa liittyvän siihen välitilaan, joka syntyy kahden todellisuuden, faktisen ja fiktiivisen, samanaikaisuuteen (metaxu). Eletään oppimisen tilassa, jossa kaikki mahdolliset maailmat ovat käytettävissä tarkastelun kohteena. ("mahdollisuuksien tila", mm. Heikkinen 2002,97 .) Työskentely edellyttää elämistä kaksoistietoisuudessa myös siinä mielessä, että opiskelija on samanaikaisesti tarinan kertoja ja henkilö, jolle kerrotut tapahtuvat. Hän voi siten varioida konkreettisia tilanteita, kokeilla itselleen vieraita suhtautumisvaihtoehtoja ja pyrkiä ymmärtämään erilaisia motiiveja, tunteita tai toimintatapoja (Boal 1995, 49).

Toimintaa voidaan tarkastella myös Meadin (1934/1962) kuvaaman minärakenteen kautta. Draamatyöskentelyssä minä toimii kahdessa alueessa: subjekti-minässä (I) ja objekti-minässä (me). Kokeva subjekti-minä toimii draamallisen kontekstin, roolihenkilön tahtona ja määrättävissä. Objekti-minä taas tarkastelee subjekti-minää ja tulee esille historiallisesti reflektoimaan subjekti-minän toimintaa. Objekti-minän organisoituminen sosiaalisesta näkökulmastaan merkitsee opiskelijalle kahdenlaista reflektointia: "Mitä ajattelen/tunnen roolihenkilönä? Mitä itse ajat- telen/tunnen roolihenkilöni ajattelusta/tunteista?"

Draaman maailma ei ole symmetrinen todellisuuden kanssa. Siihen rakennetut anomaliat ja etäännyttämiset voivat toimia oman maailman paremmin ymmärtämisessä. Uusi perspektiivi tarkastella tutkittavia ilmiöitä syntyy fiktiosta ja roolihenkilönä fiktiossa toimimisesta. Fiktiossa työskentely mahdollistaa vaikeittenkin asioiden ja tunteiden käsittelyn vaikkapa luokkatilanteissa ilman, että opiskelija joutuu paljastamaan omasta elämästään tai tunteistaan sellaista, mitä hän ei halua tuoda opiskeluryhmään. (Watkins 2001, 192.) Opiskelijan yksityisyyttä suojaavia tekijöitä ovat mm. kollektiivisesti rakennetut, fiktiiviset ja siten etäännytetyt tarinat ja roolit, joissa kuitenkin on läsnä yksittäisen opiskelijan oma tutkimuksen kohteena oleva merkityksenanto. Itsereflektiota edistävien päiväkirjojen käyttö on olennaista draamatyöskentelyssä. Reflektio on keskeinen osa draamallista oppimisprosessia myös siksi, että opiskelija tunnistaisi roolihenkilön hänessä herättämien tunteiden alkuperän ja tulisi tietoiseksi siitä, mitä tunteita hän sijoittaa roolihenkilöön (toiseen) projektiomaisesti omasta elämäntilanteestaan. Kyse on ihmisen ja hänen kokemustensa ainutlaatuisuuden ja erillisyyden sisäisestä oivaltamisesta. Kokemuksellinen ymmärtäminen tunteiden lähtökohdista auttaa häntä tunnistamaan muun muassa transferenssitunteita tulevassa työssään.

Onnistunut draamatyöskentely on aina myös terapeuttista, mutta ei terapiaa. Terapeuttisuus liittyy draaman muotoon, joka mahdollistaa tunteiden heräämisen, itseymmärryksen ja samalla yhteisöllisyyden rakentamisen.(mm. Bardy, 2003, 30.)

\section{ESTEETTISET KOKEMUKSET TIENÄ TIEDOSTAVAMPAAN ARVO-ORIENTAATIOON}

Klassinen käsitys on, että todellisuus avautuu ihmiselle totuuden (tiede), hyvyyden (etiikka) ja kauneuden (taide) välityksellä. Nonlineaarisina ja subjektiivisen luonteensa vuoksi taiteet näyttäisivät jäävän ammatillisessa ihmissuhdetyön koulutuksessa rationaalis-lineaarisen tietämisen varjoon. Todellisuuden ilmenemistapoina tiede, taide ja etiikka eivät Venkulan (2003) mukaan voi korvata toisiaan muodostaessamme tietämystä ympäröivästä todellisuudesta. Mitä taide, kauneus tai estetiikka ovat tai mitä niiden kautta voi op- 
pia, perustuu siihen, miten ne määritellään.

Filosofi Baumgarten kehitti 1700 -luvulla käsitteen estetiikka (kreik. aisthésis: aistihavainto) erottamaan kohteen (taideteos) ja kokemuksen (esteettinen kokemus, taide-elämys) toisistaan. Kohteen ja kokijan erottaminen on pragmatistisen estetiikan perusta. Sen keskeinen kysymys on, mitä ihmiselle tapahtuu esteettisessä kokemuksessa? Taiteen perimmäiseksi tavoitteeksi nousee pragmatismissa tekeminen ja kokemus, jonka saavuttamiseksi totuus ja tieto ovat välttämättömiä. (Schusterman 2001, 16-17.) Taide on pragmatismissa alisteinen tavoiteltaville päämäärille. Sellaisilla toiminnan alueilla, joissa tavoitteena on ihmisen kasvu ja eheytyminen, taiteen ymmärtäminen ensisijaisesti esteettisenä kokemuksena on luontevaa. Pragmatistisen estetiikan merkitystä sosiaali- ja terveydenhuollon alueella on tullut tunnetuksi muun muassa Unescon Ars in Hospital -hankkeen kautta, jonka tavoitteena oli kulttuurin ja taidetoiminnan saattaminen osaksi ihmisen elämää silloin, kun hän tilapäisesti tai pitempiaikaisesti joutuu sairaalahoitoon. (mm. Liikanen 2003)

Esteettiselle kokemukselle annetut merkitykset eivät avaudu koettujen tosiasioiden kautta. Vasta tunne, joka nousee kokemuksesta, avaa näkemään sellaista, jota ilman tunnekokemusta ei voi ymmärtää. Bestin $(1992,195)$ mukaan on mahdoton kuvitella muita keinoja kuin taide lähestyä oppimisessa esimerkiksi moraalia, sosiaalisia tai emotionaalisia alueita käsitteleviä aiheita. Taide tarjoaa kielen, jolla näyttäisi olevan erityinen kyky kuljettaa osallistujansa kokonaisvaltaisesti ja usein moniaistisesti tarkasteltavan ilmiön välittömään yhteyteen myös tunnetasolla ja näin ohittaa ennakoiva kokemuksen analysointi. Kokemus on siten hyvin autenttinen. Taiteen herättämä tunne toimii siltana (reflektio) itseymmärrykseen ja myös toisen ihmisen eläytyvään ymmärrykseen. Jälkimmäinen ei ole mahdollista ilman edellistä. Toista ihmistä ei voi hoitaa eläytyen, heidän tunteisiinsa vastaten, jos itse ei ole yhteydessä omiin tunteisiinsa (mm. Watkins 2001, 194).

Pragmatistinen estetiikka pyrkii osoittamaan, että esteettinen arvo voidaan johtaa moraalisista arvoista. Taiteen kokemukset saavat ihmiset tarkastelemaan ja ymmärtämään elämänsä moraalisia periaatteita. (Eaton 1995, 156.) Tieteen ja taiteen käsitys totuudesta on erilainen. Tiede kommunikoi oman määritellyn kielensä kautta. Tai- teen todellisuuden ilmaisu on elämyksellistä ja moniaistista. Tieteenfilosofi Putnam kuvaa taiteen mahdollistamaa totuutta moraaliseksi totuudeksi (emt.,157). Lövlie $(2001,27)$ käsittelee esteettistä sivistystä tiedon, moraalin ja tunteiden muodostamana kokonaisuutena, kun taas tieteellisen ajattelun ja moraalin voidaan katsoa hänen mukaansa perustuvan olemassa oleviin sääntöihin ja käsitteisiin. Taide, esteettisen kokemuksen kautta, tuo tieteelliseen tarkasteluun mukaan tunteet ja siten mahdollistaa kokonaisvaltaisemman moraalipohdinnan. Arvot avautuvat ihmiselle tunteiden kautta. Tunteiden taustalla on useimmiten tiedostamaton arvo-orientaatio. Tunnekokemukset itsessään eivät luo arvoja, mutta mahdollistavat arvoista tietoiseksi tulemisen (Puolimatka 2004, 35-36). Tunteiden nimeäminen edellyttää ensin niiden koettua tiedostamista. Bestin $(1992,195)$ mukaan tunteet ja niiden kautta tapahtuva ymmärrys, kognitiivinen päättely, eivät ole toisiaan poissulkevia, vaan kietoutuvat olennaisesti toisiinsa. Taiteen eräs keskeinen kognitiivinen vaikutus liittyy ihmisen representaation eli metaforisen ajattelun kykyyn. Taide- ja esteettiset kokemukset toimivat välittäjinä näissä arvo-orientaatioiden, tunteiden ja niistä seuraavien toimintojen tiedostamisessa ja kehittämisessä. "Taide ei varmastikaan ole mitään muuta kuin suorempi näköyhteys todellisuuteen" (Bergson 1994, 124 ).

\section{FORUMTEATTERI OPETTAJANA}

Yksi valmisteilla olevan tutkimukseni kiinnostuksen kohteista on kysymys: millainen on draamamuotoinen opiskelu opiskelijoiden kokemuksena ? Minkälaisia merkityksiä he antavat oppimiskokemukselleen ? Mitä he ilmaisevat oppineensa draamatyöskentelyn kautta ? Näihin kysymyksiin hain vastauksia yhdestä draamamuotoisesti toteutetusta opiskelukokeilusta. Kymmenen sairaanhoitajaksi opiskelevaa (mielenterveystyö ja psykiatrinen sairaanhoito) opiskelijaa toteuttivat oman opinnäytetyönsä puolentoista vuoden aikana käyttäen tiedonhankinnassa forumteatterin muotoa. Opiskelijoista puolet oli naisia ja puolet miehiä. Opiskelijat tutkivat opinnäytetyössään lasten arkipäivään liittyviä moraalivalintoja forumteatterin keinoin ja samalla heidän tutkimuksensa tarkoituksena oli saada kokemuksellista tietoa tavoitteellisesta ryhmätyöskentelystä ja uudenlaisesta työmuodosta (draama), jota he toi- 
voivat voivansa käyttää tulevassa työssään. Lähtökohtana oli Collodinin satu Pinokkio. Forumteatteri-esitys toteutettiin kahdeksan kertaa 5-9 vuotiaille lapsille. Forumteatterin muotoon rakennettu esitys mahdollisti sen, että lapset saattoivat vaikuttaa esityksen kulkuun sen sisään rakennettujen viiden ongelmatilanteen kautta, joissa Pinokkion oli tehtävä moraalinen ratkaisu (Saako valehdella? Saako ottaa toisen omaa? Voiko lupauksen pettää? Mikä on rikkomuksesta sopiva rangaistus?). Lasten oli myös perusteltava omia valinta- ja muutosehdotuksiaan. Esitykset videoitiin ja analysoitiin kirjalliseksi työksi. Opinnäytetyön toteutus edellytti analyysi- ja tiedonhankintametodin (forumteatteri) opiskelua ja hyvin intensiivistä yhdessä toimimisen kykyä.

Haastattelin opiskelijoita väljämuotoisella teemahaastattelulla kun opinnäytetyö oli hyväksytty ja valmistuminen edessä. Luin opiskelijoiden opintopäiväkirjoja opintojen edetessä ja heidän luvallaan monistin ne itselleni tutkimustani varten. Päiväkirjat muodostuivat myös ryhmän vaiheita kuvaavaksi prosessiaineistoksi. Tutkijan päiväkirjani muodosti kolmannen aineiston.

Haastattelujen analysoinnissa sovelsin Perttulan (1995; 2000) kehittämää, eksistentiaaliseen fenomenologiaan perustuvaa metodia. Aineiston käsittelyssä yhdistin kuvailevan ja tulkinnallisen tutkimusorientaation. Kiinnostukseni kohde oli opiskelijoiden kokemukset. Tutkimusote on siten lähtökohdiltaan yksilökohtaista. Analyysin lähtökohtana oli tutkittavan ilmiön kannalta merkityksellisten yksiköiden löytäminen. Pääkategorioiksi nimesin ryhmän ja draamamuotoinen työskentely. Nämä liittyivät kokemuksen merkitystä kuvaaviin yksiköihin; itsetuntemus ja persoonallinen kehitys, sukupuolten välinen yhteistyö, ryhmäohjautuvuus, tulevaisuuden työtaitojen kehittyminen, erityiset tunnekokemukset, työskentelyn uutuus/poikkeavuus. Analyysin ensimmäisen vaiheen tuloksena syntyivät kymmenen yksilökohtaista merkitysverkostoa, jotka toimivat toisen vaiheen lähtökohtana.

Fenomenologisessa tutkimustraditiossa kyse on ilmiön kuvailusta, ei sen tulkinnasta. Eksistentialismi tuo tutkimukseen mukaan myös tulkinnan. Eksistentiaalisen fenomenologian ihmiskäsitykseen liittyvä kokemusten ainutlaatuisuus merkitsee tutkijalle tietoista valintaa ja perustelevuutta, kun tutkimuksessa siirrytään etsimään ilmiön yleisiä sisältöjä (kts.Perttula 1995,32) Analyysin toisessa osassa siirryin yksilökohtai- sesta yleiseen tietoon.(kts. Perttula, 2000,439.) Tutkimuksessani perustelen yleiselle tasolle siirtymistä tutkimuksen tavoitteista käsin. Opiskelijoiden ilmaisemat oppimiskokemukselleen antamat merkitykset ovat vain yksi osa tutkittavan ilmiön ymmärrystä. Liitän ne työssäni käytettävään kontekstiin (mielenterveystyön ja psykiatrisen hoitotyön opiskelu) ja omaan, vuosikymmenten saatossa muotoutuneeseen draamatyöskentelyn käyttöteoriaan, joka pitää sisällään myös erilaisia alaa koskevia teorioita ja tutkimuksia. Empiirisen osion kiinnostuksen kohteena ovat kokemukset rajatusta, yhdessä rakennetusta draamallisesta, puolitoista vuotta kestäneestä opiskelukokeilusta ei opiskelijoiden elämän virtaan luonnollisina liittyvistä yksilökohtaisista kokemuksista. Opiskelijan kokemusmaailman kokonaisvaltaisuus ja kokeiluprosessinmerkitys siinä kokonaisuudessa avautui vain jonkin verran tutkijalle opintopäiväkirjojen kautta. Tutkijan kaksoisroolini (ohjaaja/tutkija) merkitsi vahvaa 'kietoutuneisuutta opiskelijoiden kokemusmaailmaan. Voidaan olettaa, että he ilmaisivat sellaisia kokemuksia, joita he olettivat tutkijan odottavan. (vrt. Perttula 1995, 76-77.)

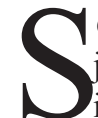

euraavassa kuvaan joitain niistä opiskelijoiden ilmaisemista kokemuksista, jotka liittyivät sekä ryhmässä opiskeluun, että tunnekokemuksiin.

Opiskelijoiden ilmaisemat kokemukset jaoin kahteen keskeisimmin esille tulleisiin, mutta useimmiten toisiinsa liittyviin pääkategorioihin: 1) ryhmään liittyviin ja 2) draamatyöskentelyyn liittyviin, sen perusteella, mihin opiskelijat ilmaisivat kokemuksensa liittyvän.

Kuvaan tutkimuksessani ryhmäkuuluvuutta osallisuuden kokemuksena. Kyse näyttäisi olevan tunnekokemuksesta, joka syntyy kuulumisesta identifioituneeseen ryhmään, jolla on oma ainutlaatuisuutensa, tehtävänsä ja koostumuksensa.

Osallisuuden kokemukset liittyvät ryhmän vaiheeseen, dynamiikkaan ja siihen, miten ryhmä on palvellut opiskelijan omaa kehitystarvetta. Yhden opiskelijan kohdalla kokemus merkitsi myös «osattomuuden» kokemusta. Ryhmän merkitystä opiskelijat kuvaavat esimerkiksi seuraavasti:

"Ehkä kaikista eniten mä oon ihmetelly matkan varrella tota ryhmän toimimista ja mitenkä kaikki on kuitenkin jaksanu olla mukana ja mi- 
ten tää ryhmä on kuin yhtä isoa perhettä. Se on ollu kaikkein isoin ihmetys. Joskus on ollu hankalaa ja vaikeeta, mutta ei mulle koskaan oo tullu sellasta tunnetta tän matkan varrella, ettei tää onnistus..." (N/4)

"Voisko sanoa, että tuli todistettua se, että mun ryhmäkokemukseni on se, että mä olen enemmän yksilökeskeinen kuin ryhmätyöskentelijä» ..»Niin mä oon näin aatellukkin olevan. Se tuli todistettua. Osaltaan varmaan luonteenpiirteistä johtuen." $(M / 1)$

"Sitten se rupes kehittyyn vahvimmin mikä aluks oli kaikkein tärkein ja sitt ryhmästä tuli mulle tän koulutuksen tärkein ryhmä". (M/10

Osa ryhmäkokemuksista liittyi sukupuolten väliseen yhteistyöhön ja erilaisuuteen. Nämä ilmaisut näyttivät liittyvän opinnäytetyön kirjalliseen työstämiseen. Esimerkiksi:

"... siinä vaiheessa kun piti tsekata koko ryhmässä yhteen juttuja piti ruveta tiukkaan puristukseen.. ryhmä jakautu kahtia. Jätkät lähti toiselle puolelle ja muijat toiselle. Ja se johtu varmaan siitä, että meillä oli toisenlainen tapa tehdä työtä ja ajatella asioista ja se oli näin helpompaa. Kun taas naisten ryhmässä oli sitä pilkun töherrystä... huomaakko se raivostuttaa mua suunnattomasti. Ja jos me oltas tehty koko ajan kirjallista työtä yhdessä, me oltas kyllä oltu toistemme kurkussa kii, kun ei miesporukassa olla totuttu sellaseen.” (M/6)

Molempiin pääkategorioihin liittyivät yksilökohtaiset oppimisalueet, kuten itsetuntemus ja persoonallinen kehitys. Ryhmä toimii minän peilinä. Seuraavassa muutama miesopiskelijoiden ilmaisema itsetuntemukseen liittyvä oppimiskokemus:

"Ennen.. mä tiedän, ett kun oli vaikee tilanne mä seisoin käet pystyssä ja sitt kun on ryhmässä joitain henkilöitä kohtaan tuntenu jotain negativivista ei oo vaan tehny sen kanssa töitä, mutt nyt kun joutu tekeen vaan vaikka oli vaikeetakin niin oppi kuunteleen toista ja näkeen muitakin puolia ja oppinu luottaan että muutkin osaa tehdä eikä mun tartte tehdä kaikkee. Ei elämän tartte olla sooloilua ja se oli hieno tunne tajuta» $(\mathrm{M} / 6)$

"Tää oli tosi suuri kasvun paikka mulle, jossa mä vahvistin niitä käsityksiä itsestäni, joita jo tiesin. Mä oon ryhmässä toimiva ihminen. Nyt mä en enää pelkää konflikteja. Mä haluun tehdä ryhmän eteen töitä. Anto mulle siis sellasen vastauksen.”(M/10)

Itsetuntemuksen kehittyminen, joka liitettiin draamamuotoiseen opiskeluun, yhdistettiin esiintymiseen, roolityöskentelyn kautta tapahtuvaan itsereflektioon ja nonverbaaliseen draamatyöskentelyyn. Myös tunteiden käsittely etäännyttäen otettiin esille merkitsevänä oppimiskokemuksena.

"Tää oli yks keino, yks tapa, yks tie tutustua itseensä ja tehdä se muiden avustuksella. Siinä pysty näkeen itsensä sivusta, havainnoida itseään ja omaa toimintaansa, asenteita ja ajatuksia kuin ulkopuolisen silmin." (M/9)

"... ja sitt kun oppi että pysty tarkasteleen itseään erilaisten roolien kautta ja sitten alko nähdä niissä draamaharjotuksissa kuinka omia patoutumia voisi tarkastella ja samalla oli kivaa ja huomas että kaikkia juttuja sun ei tarvii etkä sä voikaan käsitellä pelkästään verbaalisella tasolla vaan sun tarttikin ottaa koko kroppa mukaan ja se on vapauttanu ja antanu voimavaroja." (M/6)

$\mathrm{S}$ elkeimmät tunnekokemusten ilmaisut nousivat vahvasti emotionaalisesti sävyttyneistä ilmauksista, joita tulkitsen eriasteisena flow- tai haltioitumiskokemuksina. Lind (1995) puhuu myös huikaisevista kokemuksista, jotka auttavat oppimaan. Taustalla on Csikszentmihailyin (1991) teoria optimaalisesta psykologisesta kokemuksesta, jota voi metaforisesti verrata vapaan veden virtaukseen. Tyypillistä näille tilanteille on kaikkien aistien läsnäolo, mielen keskittyneisyys niin, että minätietoisuus ajoittain häviää. Toiminnalla on myös selkeä päämäärä ja se on mahdollista loppuunsaattaa. Taiteen eri muodot mahdollistavat flow-kokemuksia taiteen kokijoille ja taiteen tekijöille. Tunnekokemuksena flow on nautinnollinen ja palkitseva. Tulkinnassa olen ottanut huomioon haastattelutilanteessa ilmenneitä konnotaatioita ja elekieltä, jotka erosivat tavallisesta puhetavasta siirryttäessä flow-kokemuksiin.

Osa voimakkaista tunnekokemuksista liittyy ryhmässä olemiseen ja itsensä alttiiksi laittamisen kokemuksiin. Esimerkiksi:

"Tää oli mieletön kokemus... tää meiän ryhmä..Me tehtiin se hienosti loppuun asti, vaikka ei ois kaikin ajoin uskonu." (M/10)

"Sit siinä tuli sellaisia ihania hetkiä ja tunteita, sellaisia mitä ei varmaan saa mistään muu- 
alta. Se on niin paljastavaa itsellekin olla esillä, muiden nähtävänä ja samalla täysin tietoisena myös epäonnistumisen mahdollisuudesta. Se on sellasta hurjaa itsensä alttiiksi laittamista.”(M/9)

Osalle voimakkaat tunnekokemukset näyttäisi liittyvän oppimistoiminnan erilaisuuteen, uutuusarvoon ja omaan osuuteen siinä. Uutuusarvolla tiedetään olevan merkitystä tarkkaavaisuuden ylläpidossa niin oppimis- kuin terapiatoiminnassakin. Oppimistilanteen erilaisuus ja yllätyksellisyys tuo mahdollisuuden oppia näkemään vaihtoehtoisia perspektiivejä, herkistää erojen näkemiselle ja toimimaan tässä ja nyt hetkissä. (mm. Niemi 2001,23.) Esimerkiksi:

"Oli se hienoo päästä mukaan tähän juttuun. Emmä tienny, ett opiskelu vois olla tällasta..." $(N / 7)$

"Ei sitä oikeen osannu ulkopuolisille kuvata.. miten sitä nyt semmosta näyttelemistä.. ja sitt kun kerto, se tuntu niin latteelta, kun eihän ne vois ikinä ymmärtää.,"(M/6)

Haltioituneet kokemukset liittyivät myös varsinaisiin esityksiin, jännitykseen ja onnistumiseen:

"Ennen esitystä sitä jännitti ihan hurjasti ja samalla oli hurja draivi...sellanen kihelmä. . epävarma ja samalla odottava.. ja sitt hvvän esityksen jälkeen oli huikee olo. Kaikki oli... niinku mahdollista» (N/3)

$\mathrm{R}$ yhmän oppimiskokemuksista nousee muun muassa seuraavia päätelmiä:

Ryhmässä työskentely, osallisuuden kokeminen johonkin tavallisesta oppimistilanteesta poikkeavaan sävyttää draamallisen oppimiskokemuksen luonnetta. Ryhmän turvallisuus merkitsee itsetuntemuksen kehittämiseen tarvittavaa «peiliä» jonka kautta opiskelija voi itsereflektoida omaa toimintaansa, ajatteluaan, tunteitaan ja arvomaailmaansa. Tutkimus ei anna vastauksia sille, toimiiko mikä tahansa ryhmätyöskentelyyn perustuva työmuoto samalla tavoin ryhmäturvallisuutta lisäten, tai miten erityisesti draamatoiminta muuttaa ryhmädynaamista kehitystä. Päätelmänä voidaan kuitenkin sanoa, että opetuksen muotoa (forma) suhteessa sen sisältöön (materia) voidaan tarkastella, ei vain metaforisesti vaan myös analogisesti, perinteisen dramaturgian kautta, jossa muodon tarkoitus on vaikuttaa ja "uusintaa vastaanottajansa subjektina" (Reitala \& Heinonen 2001, 62). Muodon voi olettaa kantavan imp- lisiittisesti kuvaa ihmisestä ja maailmasta. Opetuksen, samoin kuin dramaturgian muoto merkitsee sellaista sosiaalista järjestystä, joka ehdollistaa vastaanottajansa. Reitalan ja Heinosen (emt., 62) mukaan muodosta tulee siten myös keskeinen vallan strategia. Draamamuotoinen opiskelu näyttäisi ehdollistavan osallistujansa tunnekokemuksille, Itseohjautuvan oppimisen ideologian positiivisena tausta-ajatteluna voi nähdä pyrkimyksen ehkäistä tämä vallan käyttö, mutta kehittyessään vallitsevaksi ideologiaksi, se saattaa muuttua vain kliseiseksi arvotraditioksi. Itseohjautuvuudesta on tullut itsetarkoitus ja totalisoiva, jolloin unohtuu ihmisen oppimisen monikerroksisuus ja etenkin kulloisenkin oppimisen kohteena olevan sisällön ja muodon yhteensopivuus. Ryhmän mahdollistavaa itseymmärryksen, toiminnan ja tunteiden reflektiota kutsun tutkimuksessani ryhmäohjautuvuudeksi, jonka merkityksen näen erittäin keskeiseksi kaikilla niillä ammatillisen koulutuksen alueilla, joissa tuleva työ on pääsääntöisesti ihmissuhdetyötä ja työryhmässä toteutuvaa. Draamatyöskentely «silloittaa» terveydenhuollon koulutustutkimuksissa todettua kuilua teorian ja käytännön välillä (mm.Karttunen 2003, 34) rakentamalla "as-if" -tilanteita, joiden välityksellä opiskelija voi harjaantua konkreettisissa tilanteissa rakentaakseen persoonallista suhdettaan tulevaan ammattiinsa.

\section{TAITEILLA TILAA TUNTEILLE AMMATTIIN KASVUSSA}

Ammatillisen koulutuksen retoriikka on kytkeytynyt muun koulutuspolitiikan ohella vallitsevaan uusliberalistiseen talouspolitiikkaan. Doing more with less -pyrkimyksissä oppimiseen käytetty aika ja resurssit ymmärretään määrällisenä tehokkuusajatteluna. (mm. Hilpelä 2001; Värri 2002.) Unohdetaan, että perusteltu ja persoonalliseen käyttöön saatu osaaminen toiminnassa ja ihmismielessä muodostuu äärettömän hitaasti. Ymmärtäminen ei tapahdu samalla nopeudella kuin tiedon hankinta ja siirtäminen. Venkulan $(2003,26)$ mukaan "Teknologisen aikamme irrationaalisuus näkyykin mm. siinä, että emme ymmärrä ihmismielen toiminnan hitautta." Koulutusyhteisöissä on ajoittain unohdettu myös opiskeltavien ammatillisten alojen erityispiirteet. Oppimisprosessi ymmärretään helposti samankaltaisena riippumatta siitä, mitä opiskellaan tai minkälaisia valmiuksia ammatillisella koulutuksella pyritään ai- 
kaansaamaan. Niillä ammatillisilla koulutusaloilla, joiden arkitodellisuus on yhdessä toimimista tunnetiiviissä työkulttuurissa, on moniulotteisen tunnemaailman ymmärtäminen keskeisimpiä koulutuksen sisältöalueita.

Terveydenhuollon koulutuksista, etenkin ammattikorkeakouluissa, taide- ja kulttuuriaineet ovat hävinneet. Niiden on oletettu integroituvan pääaineen sisälle tai ne ovat valinnaisina opintoina. Tilalle on tullut tiedon hallinta ja käsittelytaidot. Tiedon käsite on vähitellen kapeutunut käsittämään vain eksplisiittistä, tieteellisen tiedon kategoriaa. Tunnealueen opiskelussa se merkitsee teoreettista tunteista tietämistä. Introspektiivinen itsestä oppiminen, itseymmärrys, etenkin tunnealueella, on kuitenkin edellytys ymmärtää tunnemaailmaa kokemuksellisesti. Se luo perustaa tunnetyölle ammatillisessa hoitosuhteessa ja toimii myös tunneuupumuksen ennaltaehkäisijänä. Molanderin (2003) tutkimuksessa tunneväsymyksestä vanhustyötä tekevien parissa havaittiin sen syntyvän tunnetiiviiden vuorovaikutustilanteiden tiuhasta vaihtumisesta. Tunnetilojen alkuperä saattoi kadota, koetut tunteet olivat irronneet alkuperästään, mutta kasautuivat käsittelemättöminä työntekijään. Näiden tunnekokemusten reflektointia ja tunnetyötä on voitava harjoitella riittävästi opiskelussa aivan samoin kuin muitakin työhön liittyviä ammatillisia taitoja.

Eettisesti korkeatasoisena pidetyn hoitotyön koulutuksen tulisi sisältää myös esteettistä sivistystä, jota Lövlie $(2001,27)$ kuvaa tiedon, moraalin ja tunteiden kokonaisuutena. Tunnealueiden väheneminen hoitotyön korkea-asteisessa koulutuksessa merkitsee arvoperustan ohenemista. Arvo-orientaation tiedostamisessa tunteilla kun on keskeinen asema (Puolimatka 2004, 3536). Tunteet eivät aina «taivu» käsitteille ja puhutulle kielelle. Vaikeat kokemukset kätkeytyvät kognitiiviselta alueelta, eikä niitä siksi voi sanallistaa. Ne elävät kokemusmuistissa implisiittisinä. Taiteet, mahdollistaessaan esteettisiä kokemuksia ja elämyksiä, antavat «kielen» ja avoimen tilan opiskelijalle tutkia omia ja yhteisöllisiä tunteita ja niiden alla olevia arvoja eläytyen ja etäännyttäen tavalla, joka tieteelle ei ole mahdollista. Muodolla on siten merkitystä oppimiselle. Ammattikorkeakoulun pedagoginen kehittäminen merkitsee lisääntyvää tutkimusta ja keskustelua kunkin ammattialan erityisyyden esille ottamiseksi, muutoin tyydytään totalitaarisiin pedagogisiin ratkaisuihin, joiden taustalla on harhainen yleistys ammateissa osaamisen ja ammateissa toimivien ihmisten samankaltaisuudesta.

\section{KIRJALLISUUS.}

Bardy, M. (2003) Pahuuden jäljillä - sen anatomista ja kesytysharjoituksista. Kirjassa Krappala ja Pääjoki (toim.) Taide ja toiseus. Sosiaali- ja terveysalan tutkimus- ja kehittämiskeskus.

Bergson, H. (1994). Nauru. Tutkimus komiikan merkityksestä. Loki-Kirjat.

Best, D. (1992). The Rationality of Feeling. Understanding the Art in Education. London. Palmer Press.

Boal, A. (1996). Politics, Education and Change. Kirjassa O‘Toole,J. and Donelan,K. (eds.) Drama, Culture and Empowerment. IDEA Publications.

Cattanach,A. (1992) Drama for people with special needs. ( $2^{\text {nd }}$ ed) London. Drama Publishers

Csikszentmihalyi, M. (1991). FLOW The psychology of optimal experience. New York. Harper Perennial.

Eaton, M.M. (1995). Estetiikan ydinkysymyksiä. Helsingin yliopisto. Lahden tutkimus- ja koulutuskeskus.

Esslin, M. (1980). Draaman perusteet. Gummerus.

Goleman,D. (1999) Tunneäly. Lahjakkuuden koko kuva. Otava.

Heikkinen, H.(2002). Draamamaailmat oppimisalueina. Draamakasvatuksen vakava leikillisyys. Jyväskylän yliopisto.

Hilpelä, J. (2001). Uusliberalistisen koulutuspolitiikan aatteellinen tausta. Kirjassa Jauhiainen, Rinne \& Tähtinen (toim.) Koulutuspolitiikka Suomessa ja ylikansalliset mallit. Kasvatustieteellinen seura.

Hochschild, A.R. (1983). The managed heart. Commercialization of human feeling. University of California Press. Berkeley.

Isokorpi,T. (2003) Tunneälytaitojen ja yhteisöllisyyden oppiminen reflektoinnin ja ryhmäprosessin avulla. Tampereen yliopiston ammattikasvatuksen tutkimuslaitoksen ja Hämeen ammattikorkeakoulun julkaisuja 1/2003 
Karttunen,P. (2003). Tietävien käytännön osaajien kouluttaminen sosiaali- ja terveysalalla. Kirjassa: Kauppi \& Huttula (toim.). Laatua ammattikorkeakouluihin. Korkeakoulujen arviointineuvoston julkaisuja 7:2003

Kauppi,A. (2003) Ammattikorkeakoulujen koulutuksen kehityslinjoja. Kirjassa Kauppi \& Huttula (toim.) Laatua ammattikorkeakouluihin. Korkeakoulujen arviointineuvoston julkaisuja 7:2003

Levanen, L. (1998). Eläytyminen ja etäännyttäminen teatterikasvatuksessa. Acta Universitatis Tamperensis 586. Tampereen yliopisto.

Liikanen, A. (2003). Taide kohtaa elämän. Ars in Hospital-hanke ja kulttuuritoiminta itäsuomalaisten hoitoyksiköiden arjessa ja juhlassa. Otava.

Lind, R. (1995). Huikaisevat kokemukset auttavat oppimaan. Fysioterapia 4/95.

Lövlie, L. (2001). Esteettinen kokemus. Kirjassa Anna-Lena Östern (toim.) Laatu ja merkitys draamaopetuksessa. Draamakasvatuksen teorian perusteita. Jyväskylän yliopisto. Opettajakoulutuslaitos.

Mead, G.H. (1934/1962). Mind, Self and Society. University of Chicago Press.

Molander, G. (2003). Työtunteet - esimerkkinä vanhustyö. Työterveyslaitos.

Niemi, P. M. 2001). Identiteetti, muutos ja toimintaympäristö. Psykologia 1-2/01

Perttula, J. (1995). Kokemus psykologisena tutkimuskohteena. Johdatus fenomenologiseen Psykologiaan. Suomen fenomenologinen instituutti.

Perttula, J. (2000). Kokemuksesta tiedoksi. Fenomenologisen metodin uudelleen muotoilua.

Kasvatus, 31(5), 428-441

Puolimatka, T. (2004). Kasvatus, arvot ja tunteet. Tammi.

Reitala, H. \& Heinonen, T. (2001). Dramatisoitua todellisuutta. Kirjassa Reitala,H.\& Heinonen, T. (toim.). Dramaturgioita. Näkökulmia draamateorian, dramaturgian ja draama-analyysin ongelmiin. Helsingin yliopiston Tutkimus- ja koulutuskeskus. Palmelia-kustannus.

Shusterman, R. (2001). Taide, elämä ja estetiikka. Pragmatistinen filosofia ja estetiikka. Tammerpaino Oy.

Venkula, J. (2003). Taiteen välttämättömyydes- tä. Kirjapaja Oy.

Värri, V-M. (2002). Kasvatus ja "ajan henki”Tulkintoja psykokapitalismin armottomuudesta. Aikuiskasvatus 2/2002.

Watkins, P. (2001). Mental Health Nursing. The Art of Compassionate Care. Oxford. Heinemann.

Östern, A-L. (2003). Art Form into meaning in Process Drama - the Pretext as Metaphor. Kirjassa Special Interest Field of Drama, Theatre and Education. The IDEA -dialogues. Jyväskylä University Press.

\section{VIITTEET}

1 Tunneälyllä tässä artikkelissa tarkoitetaan sitä persoonallisen älykkyyden aluetta, joka pitää sisällään sekä intrapersoonallisia, itsetuntemukseen liittyviä piirteitä (mm. omien tunteiden tiedostaminen, tunteiden hallitseminen tilannesidonaisesti) ja interpersoonallisia, ihmissuhteisiin liittyviä piirteitä (mm. muiden tunteiden havaitseminen ja niiden huomioon otto)

2 Tunnetaidoilla tarkoitetaan tunneälyyn kuuluvien piirteiden joustavaa ja tilannekohtaista käyttöä

3 Hochschild (1983) otti käyttöön käsitteen tunnetyö tutkiessaan lentoemäntien ammattia, jossa tunteiden ilmaisuilla oli kaupallinen merkitys. Tunteiden hyödyntämisessä on hänen mukaansa kyse tunteiden ilmaisun institutionalistamisesta. Tunteiden ilmaisun tarkoituksena oli herättää matkustajissa turvallisuuden tunteita ja myönteistä tunnesuhdetta matkatoimistoa kohtaan. Hochschild kiinnitti huomiota ihmisen kykyyn muokata tiedostamattomasti tunteita ja siihen, miten tunteiden hyödyntämiseen liittyy aina myös moraalinen vastuu. Lisäksi tunneilmaisujen jatkuva irrallisuus todellisesta tunnekokemuksesta on persoonalle ajan kuluessa tuhoisaa. Hoitotyö on toimintaa, jota sävyttää usein voimakas tunnelatautuneisuus. Hoitajien toiminta perustuu myös ammatilliseen palveluun, jossa käytetään tunteita esimerkiksi potilaan rauhoittamiseen. Molander (2003) tutki näiden" työtunteiden" käytön merkitystä vanhustyötä tekevien parissa.

Artikkeli saapui toimitukseen 15.3.2004. Se hyväksyttiin julkaistavaksi toimituskunnan kokouksessa 15.4.2004. 